\title{
Feasibilify of Using Foamed Styrene Maleic Anhydride (SMA) Co-polymer in Wood Based Composites
}

\section{Mogućnosti primjene upjenjenog kopolimera stiren anhidrida maleinske kiseline (SMA) u kompozitima na bazi drva}

\author{
Review paper $\bullet$ Pregledni rad \\ Received-prispjelo: 11. 4. 2016. \\ Accepted-prihvaćeno: 15. 11. 2016. \\ UDK: $630 * 863$ \\ doi:10.5552/drind.2016.1624
}

\begin{abstract}
Wood plastic composites (WPCs) have often been used in consumer applications, automotive industry and exterior construction. WPCs consist mostly of wood and thermoplastic polymer. WPCs can have superior outdoor durability and much lower maintenance costs than regular wood. WPCs can be used instead of wood. Styrene maleic anhydride (SMA) is used in plastic composites for the automotive industry and also in engineering applications. SMA wood composites, as one of the WPCs using wood fibers as reinforcing fillers, produces composites with mechanical properties that are stiffer and stronger than the neat polymer. This paper evaluates the feasibility of using foamed SMA copolymer composites in wood applications. Although it is currently used in the automotive industry and construction industry, this copolymer presents interesting opportunities for wood applications.
\end{abstract}

Key words: Wood Polymer Composite, Foaming, Styrene Maleic Anhydride (SMA), Physical and Mechanical Properties

\begin{abstract}
SAŽETAK • Drvo-plastični kompoziti (WPCs) imaju vrlo široku primjenu, a uglavnom se sastoje od drva $i$ termoplastičnog polimera. Mogu imati vrhunsku trajnost na otvorenome i mnogo niže troškove održavanja od običnog drva te se mogu upotrebljavati svugdje gdje se obično upotrebljava drvo. Stiren anhidrid maleinske kiseline (SMA) primjenjuje se u plastičnim kompozitima za automobilsku industriju, ali i u tehnici. SMA drvni kompoziti jedan su od WPCs-a u kojima su drvna vlakanca punilo za ojačavanje kompozita i imaju bolja mehanička svojstva od čistog polimera. U ovom se radu procjenjuje isplativost upotrebe upjenjenih SMA kopolimera kao zamjene za drvo. Iako se zasad rabi u automobilskoj industriji i graditeljstvu, taj kopolimer ima višestruke mogućnosti primjene kao zamjena za drvo.
\end{abstract}

Ključne riječi: drvo-polimerni kompoziti, pjena, stiren anhidrid maleinske kiseline (SMA), fizikalna i mehanička svojstva

\footnotetext{
Authors are lecturers at University of Bulent Ecevit, Caycuma Vocational School, Furniture and Decoration Programme, Zonguldak, Turkey. ${ }^{2}$ Author is professor at University of Bartın, Forest Industry Engineering Department, Bartın, Turkey. ${ }^{3}$ Authors are lecturers at School of Forest Resources, Advanced Structures and Composite Center, Maine, USA.

Autori su predavači Sveučilišta Bulent Ecevit, Strukovna škola Caycuma, Program za namještaj i dekoracije, Zonguldak, Turska. ${ }^{2}$ Autor je profesor Sveučilišta u Bartinu, Zavod za industriju baziranu na šumi, Bartın, Turska. ${ }^{3}$ Autori su predavači Škole za šumske resurse, Centar za napredne strukture i kompozite, Maine, SAD.
} 


\section{INTRODUCTION TO WOOD PLASTIC COMPOSITE TECHNOLOGY}

1. UVOD U TEHNOLOGIJU DRVO-PLASTIČNIH KOMPOZITA

Wood plastic composite (WPC) is a general term related to wood-based elements like lumber, veneer and fibers, where they are combined with polymers to produce a composite material. Wood plastic composites are thought of interchangeably and are categorized as different material types when produced from either thermoplastic or thermosetting polymers (Forest Products Laboratory, 2010). Examples of wood plastic composites made from different polymer types and wood elements are listed in Table 1.

Approximately one hundred years ago, a composite material combining phenol-formaldehyde resin with wood flour was used for making automobile gearshift knobs (Gordon, 1988). Around 60 years ago, there are references to combining wood with thermoplastic resin via extrusion processing (Oksman and Sain, 2008; Klyosov, 2007). Extrusion, injection and compression molding are the preferred production processes for WPCs (Figure 1).

WPC has gained the interest of material engineers because of its structural properties (El-Haggar and Kamel, 2011). Some of its main properties are high durability, low maintenance, strength and stiffness, lower prices and decrease in bio-degradation, which makes the composites suitable for outdoor applications. Some of the applications of these composites are: decking, sheathing, roof tiles, window trim and automobile parts. WPCs perform like conventional wood; however they are not stiff and may require special fasteners or design changes. WPCs are still stiffer than plastics (Clemons and Caufield, 2005). A developing class of materials, including WPC has favorable attributes - they are cost effective and have good performance (Marutzky, 2004; Bledzki et al., 2002; Sperber, 2002; Riedel and Nickel,2003; Aydemir et al., 2014a; Aydemir et al., 2014b; Aydemir et al., 2015a; Aydemir et al., 2015b).

\section{FOAMING PROCESSING OF NATURAL} FIBER-FILLED COMPOSITES

2. PROCES PJENJENJA KOMPOZITA ISPUNJENIH PRIRODNIM VLAKNIMA

Blowing agents, nucleating agents and other necessary additives are responsible for creating foams in a polymer (Baker, 2000). Both physical



Figure 1 Wood fiber filled thermoplastic composites (WPCs) and their applications (Anonymous, 2016a) Slika 1. Termoplastični kompoziti punjeni drvnim vlakancima i njihova primjena (Anonymous, 2016a)

and chemical blowing agents contribute to a foamed polymer. Volatile chemicals like chlorofluorocarbons, hydrocarbons/alcohols, and inert gases $\left(\mathrm{CO}_{2}\right.$, $\mathrm{N}_{2}$, Argon, and Water) are considered physical blowing agents, with $\mathrm{CO}_{2}$ being the most commonly used (Han et al., 1976; Punnathannam, 2002) (Figure 2).

The esterification reaction between the hydroxyl groups of wood and the anhydride groups of SMA generates water, which is used as a foaming agent. The density of neat SMA is $1.08 \mathrm{~g} / \mathrm{cm}^{3}$ and of the foamed SMA/wood composites $0.60 \mathrm{~g} / \mathrm{cm}^{3}$ (Han and Gardner, 2010).

The water by-product of the esterification reaction between SMA and wood is strategically created during the carboxylic acid and alcohol reaction process (Figure 3.). A contaminant from hemicelluloses degradation can be removed after the acids react with alcohols, which produces one mol of ester and another mol of water as a by-product. A hydroxyl group breaks the furan anhydride structure as an electron donator and esterifies with the hydroxyls of wood, which produces water as a by-product (Han and Gardner, 2010) (Figure 4).

Under extrusion processing, a large, soluble amount of a blowing gas into a polymer may be completely dissolved under a high pressure. How-

Table 1 Wood-plastic composites (WPCs) are materials comprising polymers and wood elements (Gardner et al., 2015) Tablica 1. Drvo-plastični kompoziti (WPCs) - materijali koji sadržavaju polimere i drvne elemente (Gardner et al., 2015.)

\begin{tabular}{|l|l|l|}
\hline \multicolumn{1}{|c|}{$\begin{array}{c}\text { Polymer type } \\
\text { Vrsta polimera }\end{array}$} & \multicolumn{1}{|c|}{$\begin{array}{c}\text { Wood elements } \\
\text { Drvni materijal }\end{array}$} \\
\hline $\begin{array}{l}\text { Thermoplastic polymer } \\
\text { termoplastični polimer }\end{array}$ & $\begin{array}{l}\text { Wumber, veneer, fibers, particles, flour, etc. } \\
\text { piljenice, furnir, vlakanca, iverje, drvno } \\
\text { brašno } i \text { dr. }\end{array}$ & $\begin{array}{l}\text { Extruded lumber, injection-molded automotive } \\
\text { components } \\
\text { ekstrudirana građa, injekcijski prešani automobil- } \\
\text { ski dijelovi }\end{array}$ \\
\hline $\begin{array}{l}\text { Thermosetting polymer } \\
\text { termostabilni polimer }\end{array}$ & $\begin{array}{l}\text { Lumber, veneer } \\
\text { piljenice, furnir }\end{array}$ & $\begin{array}{l}\text { Polymer impregnated wood (impreg, compreg) } \\
\text { polimerom impregnirano drvo (impreg, compreg) }\end{array}$ \\
\hline
\end{tabular}



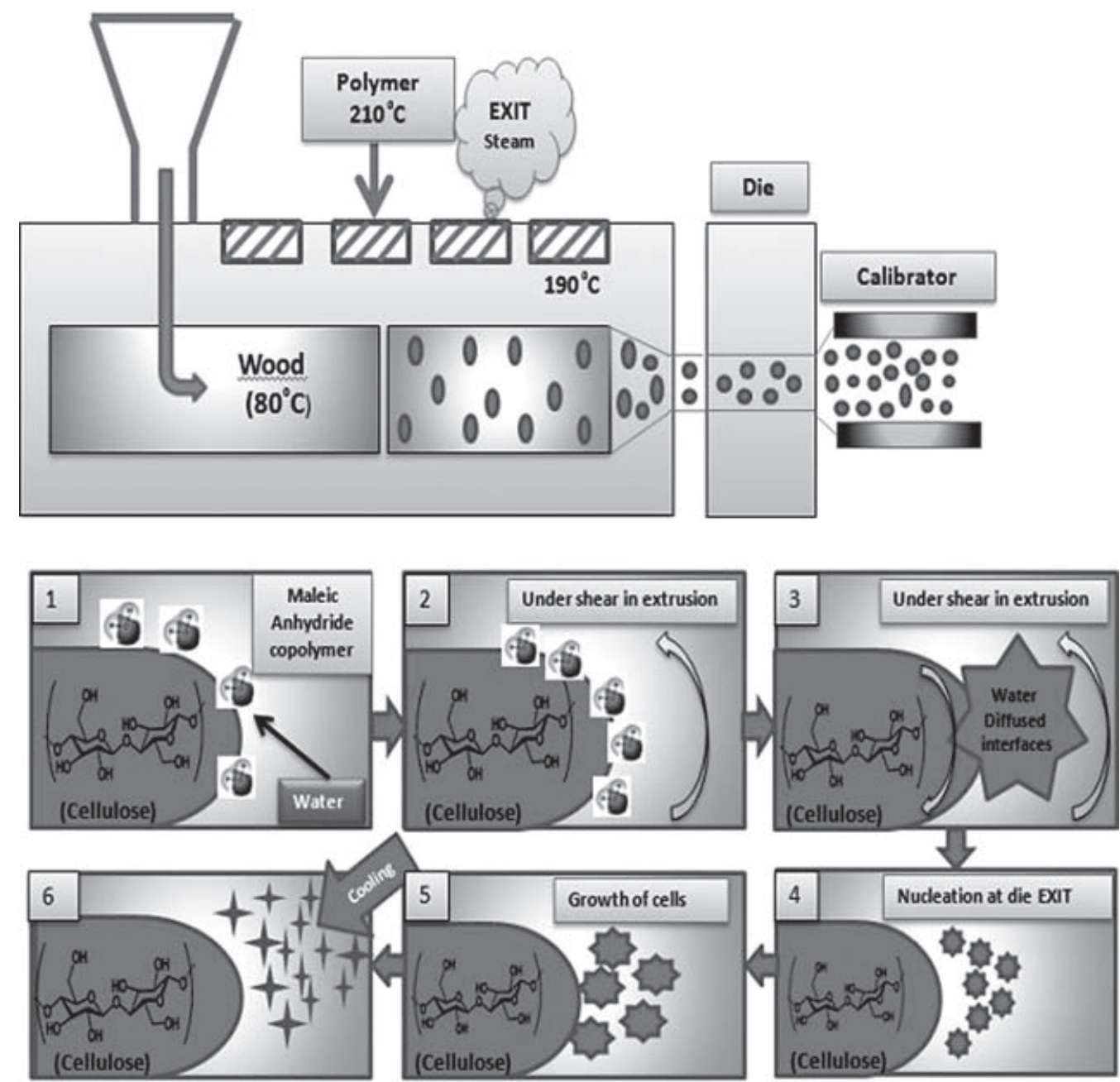

Figure 2 Foaming mechanism with natural fiber-filled composite

Slika 2. Mehanizam pjenjenja kompozita ispunjenih prirodnim vlaknima

ever, to reach appropriate conditions in the microcellular foaming system, there must be a mechanism for regulating the growth of bubbles and additionally preventing them from coalescing and collapsing (Park et al., 1994; Park and Suh, 1996; Baldwin et al., 1996; Park et al., 1998).

The generation of high cell density for foaming may be possible when thermodynamic instability happens in a polymer gas solution. These newly formed cells should be preserved through a stabilization process that controls the growth of the cells and re-equates the gas bubbles (Park and Suh, 1996; Park et al., 1994). During initial testing, a batch process was used to create micro cellulose foams. Now, these foams are produced in continuous extrusion, injection and compression molding systems (Martini et al., 1982).

Extrusion is one of the most commonly used plastic technologies. In extrusion, there are several ways to transform a plastic resin including heated, melted, compressed and conveyed downstream by rotating screw/screws in a barrel. In terms of cost effectiveness, extrusion based technologies are leading in the commercial production of plastics. As compression molding gently shapes thermoplastic prepregs, it successfully retains different layer orientations (Faruk et al., 2007). Wood fiber reinforced plastic composites are converted by extrusion processes to get structural building profiles including, sheathing, decking, roof tiles, and window trim,

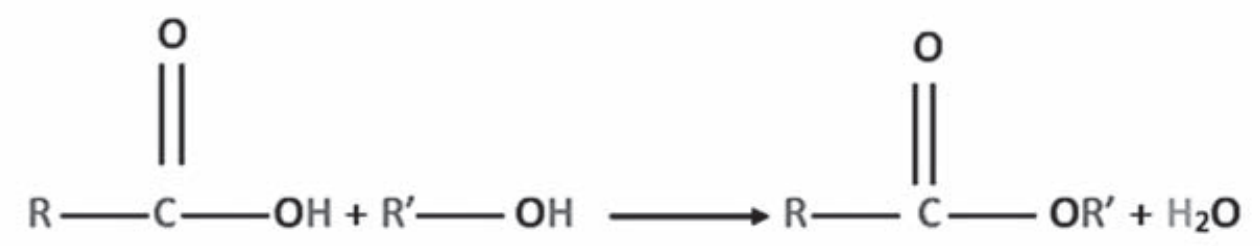

Figure 3 Typical chemical reactions between carboxyl acids and alcohols with acid catalyst (Anonymous, 2016b)

Slika 3. Tipične kemijske reakcije između karboksilne kiseline i alkohola s kiselim katalizatorom (Anonymous, 2016b) 




Figure 4 Schematic representation of the interfacial reaction between SMA copolymer and cellulose (Kiziltas et al., 2016) Slika 4. Shematski prikaz interfacijalne reakcije između SMA kopolimera i celuloze (Kiziltas et al., 2016.)

with enhanced thermal and creep performance compared with unfilled plastics (English and Falk, 1996; Verhey and Laks, 2002).

Usually, the production of foamed polymers comes from blowing agents such as a gas, a liquid or solid (Klempner and Frisch, 1991; Tavasoli et al., 2011). There are limitations of using blowing agents because they have a negative impact on the ozone layer. On the other hand, common aliphatic hydrocarbons are highly flammable. The blowing agents have a high price and low gas concentration during their decomposition (Rizvi et al., 2000). The government continues to promulgate regulations aimed at enhancing environmental protection and worker safety. Developing environmentally friendly blowing agents should help in addressing regulations and save on chemicals (Seo et al., 2011). Since water is available, non-toxic and environmentally friendly, it can be used as a blowing agent in the production of foams in the extrusion process when transformed into a gaseous state at temperatures above $100^{\circ} \mathrm{C}$.

Several studies have been published on thermal analysis of fillers that can be employed as both nucleating agents and reinforcing components. To enhance performance aesthetics, processability and productivity, many additives in foamed composites are necessary (Klempner and Frisch, 1991). When it comes to the use of natural fillers, such as cellulose particles, it appears to have advantages over inorganic fillers and properties of the fillers that can be changed by either surface treatment or the use of coupling agents (Maldas and Kokta, 1991; Wang et al., 2003; Mishra and Patil, 2003). Fiber properties (orientation of fibers and natural properties of fiber), combined with the use of coupling agents, may enhance the properties of the composite manufactured (Andrepoulus and Trantili, 1988). Natural fibers are much preferred for use in commodity plastics because of their easy processability (Raj et al., 1992). After all, natural fiber-filled polymer composites commonly have high densities. Therefore, the composites can be foamed to lessen their density using chemical or physical blowing agents (Rizvi et al., 2000). Natural filler reinforced composites have shown excellent performance regarding physical, mechanical and thermal properties (Ozen et al., 2013; Kiziltas et al., 2014).
Even though, lignocelluloses and wood fiber reinforced composite are used in automotive and decking application, their use is limited because of lower impact resistance and higher density in comparison to neat plastics (Matuana and Heiden, 2004).

The likely innovative applications of these materials could be increased if these advantages were improved. The reduced weight of foamed plastic makes it stronger than non-foamed analogs, and also makes it achieve outstanding cost to performance ratios, as well as favorable strength to weight ratios. Foamed wood fiber reinforced composites enhance their capability to withstand constant nailing and screwing operations in comparison to un-foamed products of the same composition. In the end, the results are better surface definition and sharper contours and corners. Plasticizing effects of gas and foamed composites reduce the cost of the foaming process (Schut, 2001). The specifics of mechanical properties are significantly improved when microcellular wood fiber reinforced composite generate a finer microcellular structure. Microcellular foamed structures are created to enhance the performance in the composites (Matuana et al., 1996).

\section{CHARACTERISTIC PROPERTIES OF FOAMED SMA \\ 3. KARAKTERISTIČNA SVOJSTVA UPJENJENOG SMA KOPOLIMERA}

Foamed styrene-wood plastic composites (FSWPC) have been produced at the Advanced Structures and Composites Center at the University of Maine using reactive extrusion (Han et al., 2013). To prevent loss of blowing agents through venting, they are created by chemical reaction during the extrusion process and dissolved into the polymer melt, where the dissolution occurs in the mixing zone of the barrel next to the venting zone. Supercritical water is formed under the high pressure and high temperature enabling foaming cells to locally initiate and grow to a certain size level. For the creation and maintenance of supercritical water, the extrusion system should be developed for appropriate pressure levels with a foaming die.

The industrial manufacturing arena has paid significant attention to the use of wood as reinforc- 




Figure 5 Comparison of flexural modulus of various wooden materials for structural applications (Wood-1 - Red Maple; Wood-2 - White Oak; Wood-3 - Douglas Fir = South; GL - Glued laminated timber; PLY - Plywood; OSB - Oriented Strand Board; PB - Particleboard; MDF - Medium Particleboard (Wood Handbook, 2010); WPC-1 - PP-based $60 \%$ wood (Wechsler et al., 2008); WPC-2 - Recycled PE-based $40 \%$ wood (Najafi and Khademi-Eslam, 2011); WPC-3 - SMA-based wood plastic composite, a pilot product of sheet pile by University of Maine) (Han and Gardner, 2010) (Maximum values are shown)

Slika 5. Usporedba modula elastičnosti različitih drvenih materijala za građevinske konstrukcije (Wood-1 - javor; Wood-2 bijeli hrast; Wood-3 - duglazija; GL - lijepljena drvna građa; PLY - furnirska ploča; OSB - OSB ploča (ploča s orijentiranim iverjem); PB - ploča iverica; MDF - MDF ploča (ploča vlaknatica srednje gustoće) (Wood Handbook, 2010.); WPC-1 - ploče na bazi PP-a s udjelom drva od 60 \% (Wechsler et al., 2008.); WPC-2 - reciklirane ploče na bazi PE-a s udjelom drva od 40 \% (Najafi i Khademi-Eslam, 2011.); WPC-3 - drvo-plastični kompoziti na bazi SMA-a, pilot-proizvod Sveučilišta u Maineu) (Han i Gardner, 2010.) (prikazane su maksimalne vrijednosti)

ing filler for thermoplastics (Kishi et al., 1988; Maidas et al., 1988; Woodhams et al., 1984; Yam et al., 1990). The injection molding process and thermoforming of interior parts is used along with styrene maleic anhydride (SMA) copolymer in the automotive industry (ARCO Chemical Company, 1990). The main reason for the choice of maleic anhydride is to improve the properties of the copolymer. The importance of using SMA lies in the fact that it shows a similar behavior to maleic anhydride polypropylene (MAPP) (Takase and Shiraishi, 1989). The other advantages of using SMA plastics in automobiles include the fact that SMA can be recycled and combined with other materials in order to improve the strength properties. Filler effect, reinforcement of polymer, and superior mechanical properties can be improved by using glass fillers. These fillers have shortcomings with regard to environmental safety. Natural fillers can improve the environmental effects. Using natural fillers will enhance mechanical and thermal properties; low density, high aspect ratio and no abrasiveness are beneficial properties (Bledzki et al., 2002; Sperber, 2002; Riedel and Nickel, 2003).

Over the past several decades, it has been established that foamed composites provide high cost sav- ings (30-40\%), lower density and rapid manufacturability attributable to its properties (Faruk et al., 2007; Bledzki and Faruk, 2005; Bledzki and Faruk, 2006).

Micro-fibrillated cellulose, using water as a foaming for PLA matrix composites, was investigated by Boissard et al., (2011). It was found that density and morphological properties of the foams were related to processing temperatures and to water contents ranging from 3.7 to 98 wt.\%. To obtain lower densities, a low processing temperature and MFC water content of $9 \mathrm{wt} . \%$ were required.

Polystyrene/wood foamed composites were studied by Rizvi et al., (2000), who used hydrocerol compounds and wood particle water (moisture content of $8 \%$ ) at $130{ }^{\circ} \mathrm{C}$ and $140{ }^{\circ} \mathrm{C}$. These results have shown that expansion ratio was 9 to $20 \%$.

During the last decade, bigger profiles and density reductions (5-50 \%) have been achieved in foamed wood composites including ABS, ASA, SAN, PVC, PP, and monolayer, coextruded and even tri-extruded profiles (Bledzki and Faruk, 2006).

Figure 5 shows the difference in mechanical properties when compared to other wood composites when designing structures. The flexural modulus of elasticity or stiffness is not the only mechanical properties that needs to be considered. 


\section{ADHESIVE BONDED JOINTS OF WOOD} PLASTIC COMPOSITES

4. LIJEPLJENI SPOJEVI DRVO-PLASTIČNIH KOMPOZITA

Many articles have studied the characteristics of WPC bonding (Gramlich et al., 2006; Oporto et al., 2007; Gupta and Laborie, 2007; Laborie and Gupta, 2008; Wolkenhauer et al., 2008; Oporto et al., 2009), specifically polyolefins (Kharitonov and Kharitonova, (2009); Lee et al., (2009); Pandiyaraj $\mathrm{KN}$, et al., (2009); Wang et al., (2009); Farris et al., (2010); Jacobs et al., 2010; Kirk et al., (2010)) and wood treatments (Custodio, et al., 2008; Wolkenhaure et al., 2009; Custodio et al., 2009).Various methods of surface treatments on wood plastic composites have been reported by Gramlich et al., (2006); Oporto et al., (2007); Gupta and Laborie,
(2007); Laborie and Gupta, (2008); Wolkenhauer et al., (2008); Oporto et al., (2009) to improve adhesive bonding. These surface treatments resulted in the increase of joint strength.

More research should be made on load carrying capacity of WPC joints as they are used in structural applications. So, this research will help identify the most effective design and cost considerations (Vinson, 1989). Some research has been conducted on bolted joints of WPC panels; however, further research is required (Thoppul et al., 2009). There is no current evidence of the effect of geometrical configuration of screws, pilot hole diameter and penetration depth on withdrawal resistance of related joints of WPC composites.

WPC is used commercially in automotive interiors, furniture, packaging and housing. There are

(a)

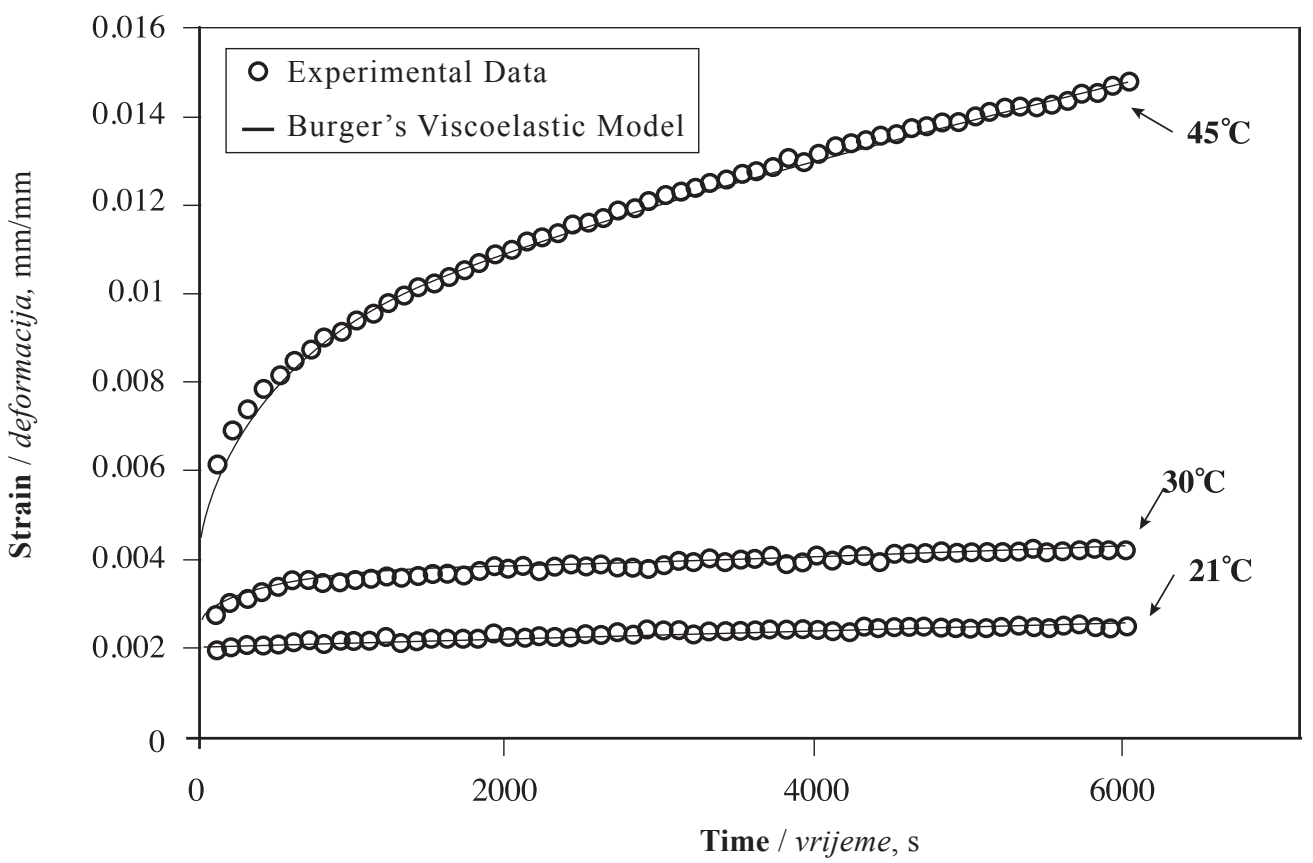

(b)

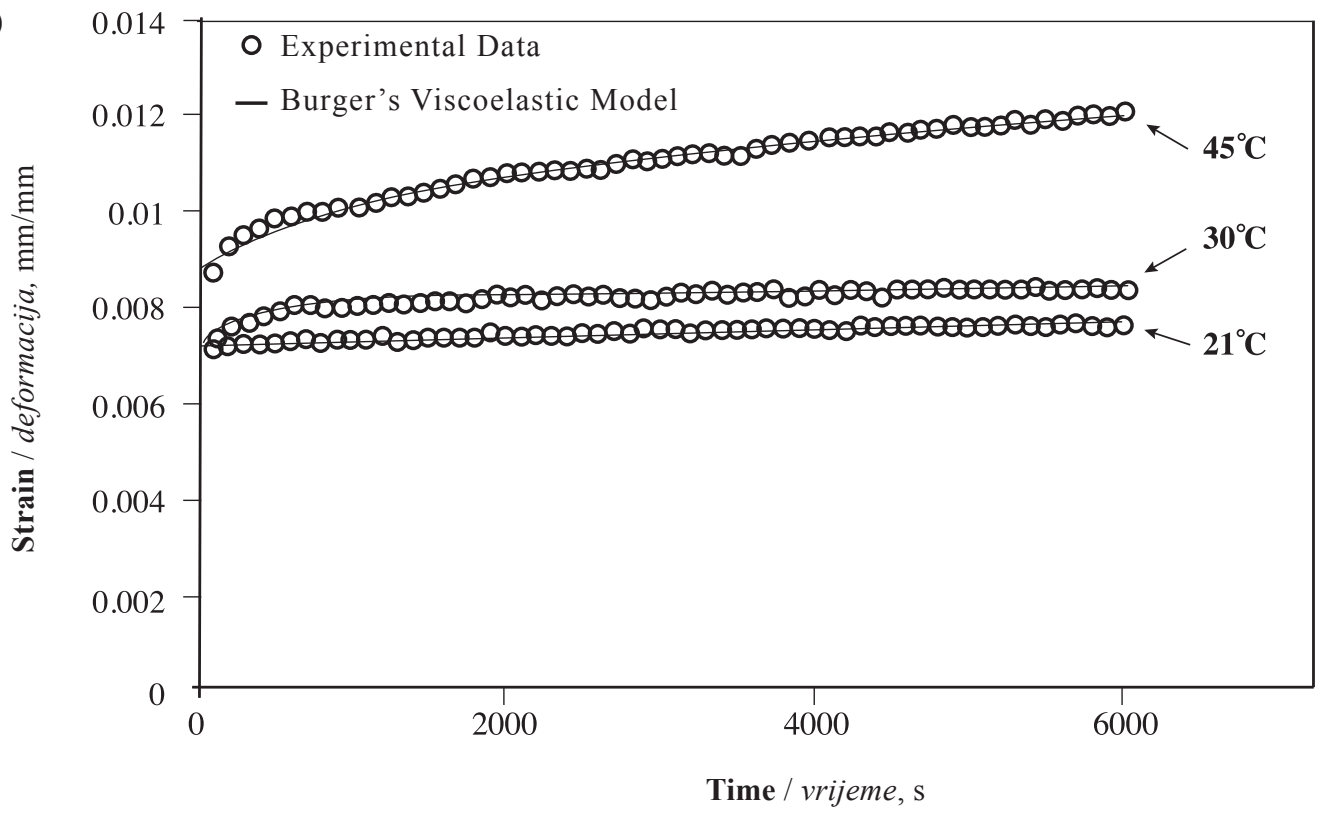

Figure 6 Short-term creep response of (a) WPC and (b) PVC (Tamrakar et al., 2011)

Slika 6. Kratkoročni odgovor puzanja materijala (a) WPC-a i (b) PVC-a (Tamrakar i sur., 2011.) 
some critical factors that affect the application of wood plastic composites (English and Falk, 1996). These are:

Cost

There are many variables affecting costs, including cost of compounding fillers, wood and paper fibers or inorganic fillers. Fillers are often less expensive than the polymer on a price per weight basis.

Hygroscopicity

Wood fiber is hygroscopic and when used in the plastic process at normal processing temperatures, the plastics will foam attributable to steam. Water is occasionally used for a foaming agent in plastic lumber profiles.

Fiber loading limits

A continuous thermoplastic matrix is required to process WPC. Upper fiber loading limit is about $70 \mathrm{wt} . \%$. To maintain ideal melt viscosity, the fiber loading limit is around $50 \mathrm{wt.} \%$ (Charrier, 1991).

Water absorption

There is little water absorption when wood component is surrounded by the plastics. Even when immersed for several days, the water absorption values are typically less than $2 \%$. Humidity variation has shown little effect on dimensional changes (Kokta and Danueault, 1986).

Engineering properties

An engineering property is the capability of WPC to safely resist the expected loads. Another property is the short and long term serviceability limits when functioning within the design load. Creep

Creep is related to the wood's ability to sustain shape during time dependent mechanical loading. Research shows that WPC has lower resistance to creep deflection, which reduces its structural applications (Felby, 1992).

Figure 6 shows the short term creep response of WPC and polyvinyl chloride (PVC) at three different temperatures $\left(21{ }^{\circ} \mathrm{C}, 30{ }^{\circ} \mathrm{C}\right.$ and $\left.45{ }^{\circ} \mathrm{C}\right)$. According to Tamrakar et al. (2011), creep deformation of WPC was lower and more stable at $21^{\circ} \mathrm{C}$ and $30{ }^{\circ} \mathrm{C}$ than that of PVC.

\section{CONCLUSION}

\section{ZAKLJUČAK}

Natural fiber-filled plastic profiles are used as a non-structural wood-replacement in specific applications such as decking. Processors are evaluating foamed composites, which weigh less, accept screws and nails and more closely resemble real wood. Foaming gives better surface definition and sharper contours and corners because of internal pressures created by foaming. Heavier foamed profiles can be joined like conventional wood with no caps or hiding edges. Most wood foamed profiles are combined with un-foamed cap layers to provide color, decoration or UV stability, which provides important structure engineering applications.
In recent years, an increasing number of attempts have been made to combine wood with plastics to create interiors (window or door frames, staircase railings, screens and even decorative items), garden furniture and other outdoor applications (terrace decking, weatherboarding and fencing panels).

Industry and academia are now evaluating foam-like structure in WPCs to decrease their density and cost, improve mechanical properties (impact strength and toughness), nailing and screwing properties.

\section{REFERENCES}

6. LITERATURA

1. Andrepoulos, A. G.; Trantili, P. A., 1988: Water sorption characteristics of epoxy resin-UHMPE fibers composites. J. Appl. Polym. Sci., 70: 747-755.

http://dx.doi.org/10.1002/(SICI)1097-4628(19981024) 70:4<747::AID-APP14>3.0.CO;2-U.

2. Aydemir, D.; Kiziltas, A.; Gardner, D. J.; Han, Y.; Gunduz, G., 2014b: Influence of Micro- and Nanonatural Fillers on Mechanical and Physical Properties of Foamed SMA Composites. Polymer-Plastics Technology and Engineering, 53: 1825-1831. http://dx.doi.org/10.1080/03602559.2014.935406.

3. Aydemir, D.; Kiziltas, A.; Gardner, D. J.; Han, Y.; Gunduz, G., 2014a: Morphological characterization of foamed natural filler-reinforced styrene maleic anhydride (SMA) composites. J Porous Mater, 21: 1059-1067. http://dx.doi.org/10.1007/s10934-014-9856-X.

4. Aydemir, D.; Kiziltas, A.; Gardner, D. J.; Han, Y.; Gunduz, G., 2015a: Thermal Analysis of Micro- and Nano Lignocellulosic Reinforced Styrene Maleic Anhydride Composite Foams. International Journal of Polymer Anal. and Charact., 20: 231-239.

http://dx.doi.org/10.1080/1023666X.2015.1012792.

5. Aydemir, D.; Kiziltas, A.; Gunduz, G.; Han, Y.; Gardner, D. J., 2015b: Natural fillers-filled Styrene Maleic Anhydride Copolymer Composites. Wood Research, 60 (1): 167-174.

6. Baker, R. W., 2000: Membrane Technology and Application, 1st edn. (McGraw Hill, New York), p. 368.

7. Baldwin, D. F.; Park, C. B.; Suh, N. P., 1996: An extrusion system for the processing of microcellular polymer sheets: Shaping and cell growth control. Polymer Engineering Science, 36: 34. http://dx.doi.org/10.1002/pen.10537.

8. Bledzki, A. K.; Sperber, V. E.; Faruk, O., 2002: Rapra Review Reports, Vol.13, No. 8.

9. Bledzki, A. K.; Faruk, O., 2005: Effects of the chemical foaming agents, injection parameters, and melt-flow index on the microstructure and mechanical properties of microcellular injection-molded wood-fiber = polypropylene composites. J. Appl. Polym. Sci., 97: 1090-1096. http://dx.doi.org/10.1002/app.21685.

10. Bledzki, A. K.; Faruk, O., 2006: Injection molded microcellular wood fiber polypropylene composites. Compos. J., 37: 1358-1367.

http://dx.doi.org/10.1016/j.compositesa.2005.08.010.

11. Boissard, C. I. R.; Bourban, P. E.; Tingaut, P.; Zimmermann, T.; Manson, J. S., 2011: Water of functionalized microfibrillated cellulose as foaming agent for the elaboration of poly(lactic acid) biocomposites. J. Reinf. Plast. Compos., 30 (8): 709-719.

http://dx.doi.org/10.1177/0731684411407233. 
12. Charrier, M. P., 1991: Polymeric materials and processing: plastics, elastomer, and composites. Oxford Univ. Press., New York, N.Y.

13. Clemons, C. M.; Caulfield, D. F., 2005: Natural fibers. Functional fillers for plastics. Weinheim: Wiley-VCH, pp. 195-206.

14. Custodio, J.; Broughton, J.; Cruz, H.; Winfield, P., 2009: Activation of timber surfaces by flame and corona treatments to improve adhesion. Int J Adhesion and Adhesive, 29: $167-172$ http://dx.doi.org/10.1016/j.ijadhadh.2008.03.003.

15. Custodio, J.; Broughton, J.; Cruz, H.; Hutchinson, A. R., 2008: A review of adhesion promotion techniques for solid timber substrates. J Adhesive, 84: 502-529. http://dx.doi.org/10.1080/00218460802161558.

16. El-Haggar, S. M.; Kamel, M. A., 2011: Wood Plastic Composites, Advances in Composite.

17. English, B. W.; Falk, P., 1996: Factors that affect the application of wood fiber-plastic composites. Woodfiber Plastic Composites. Forest Products Society, Proceedings, 7293: 189-194.

18. Farris, S.; Pozzoli, S.; Biagioni, P.; Duo, L.; Mancinelli, S.; Piergiovanni, L., 2010: The fundamentals of flame treatment for the surface activation of polyolefin polymers - a review. Polymer, 51: 591-605. http://dx.doi.org/10.1016/j.polymer.2010.05.036.

19. Faruk, O.; Bledzki, A. K.; Matuana, L. M., 2007: Microcellular foamed wood plastic composites by different processes: a Review. Macromolecular Materials and Engineering, 292: 113-127. http://dx.doi.org/10.1002/mame.200600406.

20. Felby, C., 1992: The Properties and Use of Materials Made From Recycled Wood and Plastics. MS thesis. The Royal Vetennary and Agric. Univ. of Copenhagen, Copenhagen, Denmark.

21. Forest Product Laboratory, 2010: Wood handbook-wood as an engineering material. General Technical Report FPL-GTR-190. Madison: Department of Agriculture, Forest Service, Forest Products Laboratory, p. 508.

22. Gardner, D. J.; Han, Y.; Wang, L., 2015: Wood-plastic composite technology. Current Forestry Reports. http://dx.doi.org/10.1007/s40725-015-0016-6.

23. Gordon, J. E., 1988: The new science of strong materials (or why you do not fall through the floor). Princeton: Princeton University Press, p. 179.

24. Gramlich, W. M.; Gardner D. J.; Neivandt, D. J., 2006: Surface treatments of wood - plastic composites (WPCs) to improve adhesion. J Adhesion Sci. and Technology, 20 (16): 1873-1887. http://dx.doi.org/10.1163/156856106779116623.

25. Gupta, B. S.; Laborie, M. P. G., 2007: Surface activation and adhesion properties of wood-fiber reinforced thermoplastic composites. J Adhes, 83: 939-955. http://dx. doi.org/10.1080/00218460701751814.

26. Han, C. D.; Kim, Y. W.; Malhotra, K. D., 1976: A study of foam extrusion using a chemical blowing agent. J. Appl. Polym. Sci., 20 (6): 1583-1595. http://dx.doi.org/10.1002/app.1976.070200615.

27. Han, Y.; Gardner, D. J., 2010: Foamed styrene-based WPC using physical blowing agent created during reactive extrusion, $10^{\text {th }}$ International Conference on Wood and Biofiber Plastic Composites and Cellulose Nanocomposites Symposium, Madison, WI, May 11-13.

28. Han, Y.; Gardner, D. J.; West, C., 2013: Structural wood plastic composite foams via reactive extrusion. Window \& Door Manufacturers Association Technical Conference. Milwaukee, Wisconsin, May, 2013. http://www. forestprod.org/fiberpolymer/about.html, Accessed: 02.17.2016.
29. Jacobs, T.; Carbone, E.; Morent, R.; Geyter, N. De.; Reniers F.; Leys, C., 2010: Surface modification of polymer films with a remote atmospheric pressure d. c. glow discharge: influence of substrate location. Surface and Interface Analysis, 42: 1316-1320. http://dx.doi.org/10.1002/ sia.3319.

30. Kharitonov, A. P.; Kharitonova, L. N., 2009: Surface modification of polymers by direct fluorination: a convenient approach to improve commercial properties of polymeric articles. Pure and Applied Chemistry, 81: 451471. http://dx.doi.org/10.1351/PAC-CON-08-06-02.

31. Kirk, S.; Strobel, M.; Lee, C. Y.; Pachuta, S. J.; Prokosch, M.; Lechuga, H.; Jones, M. E.; Lyons, C. S.; Degner, S.; Yang, Y.; Kushner, M. J., 2010: Fluorine plasma treatments of polypropylene films, 1-surface characterization. Plasma Processes Polym, 7: 107-122. http://dx.doi.org/10.1002/ppap.200900111.

32. Kishi, H.; Yoshioka, M.; Yamanoi, A.; Shiraishi, N., 1988: Composites of wood and polypropylenes I. Mokuzai Gakkaishi, 43 (2): 133-139.

33. Kiziltas, A.; Nazari, B.; Gardner, D. J.; Bousfield, D. W., 2014: Polyamide 6-cellulose composites: Effect of cellulose composition on melt rheology and crystallization behavior. Polym. Eng. Sci., 54 (4): 739-746.

http://dx.doi.org/10.1002/pen.23603.

34. Kiziltas, E. E.; Kiziltas, A.; Nazari, B.; Gardner, D. J.; Bousfield, D. W., 2016: Glycerine treated nanofibrillated cellulose composites. Journal of Nanomaterials, 7851308.v2 (submitted).

35. Klempner, D.; Frisch, K. C., 1991: Handbook of Polymeric Foams and Foam Technology. Hanser Gardner Publications (Distributed in the U.S. and Canada by Oxford University Press, New York.), $584 \mathrm{~s}$.

36. Klyosov, A. A., 2007: Wood-plastic composites. John Wiley\& Sons, p.702.

37. Kokta, B. V.; Danueault, D., 1986: Use of grafted aspen fibers in thermoplastic composites. Polymer Composites.

38. Laborie, M. P. G.; Gupta, B., 2008: Oxyfluorination of wood-fiber reinforced thermoplastic composites to improve adhesion. The Journal of Adhesion, 84: 830-846. http://dx.doi.org/10.1080/00218460802443311.

39. Lee, K. T.; Goddard, J. M.; Hotchkiss, J. H., 2009: Plasma modification of polyolefin surfaces. Packag Technol Sci, 22: 139-150.

40. Maidas, D.; Kokta, B. V.; Raj, R. G.; Sean, S. T., 1988: Use of wood fibers as reinforcing fillers for polystyrene. Materials Sci. and Engineering, A104: 235-244. http://dx.doi.org/10.1016/0025-5416(88)90425-9.

41. Maldas, D.; Kokta, B. V., 1991: Influence of organic peroxide on the performance of maleic anhydride coated cellulose fiber-filled thermoplastic composite. Polym. J. 23 (10): 1163-1171. http://dx.doi.org/10.1295/polymj.23.1163.

42. Martini, J. E.; Suh, N. P.; Waldman, F. A., 1982. The production and analysis of microcellular thermoplastic foams. Waldman, SPE ANTEC Technical Papers, 674.

43. Marutzky, R., 2004: Fifth Global Wood and Natural Fiber Composites Symposium, April 27-28, Kassel, Germany.

44. Matuana, L. M.; Park, C. B.; Balatinecz, J. J., 1996: SPE ANTEC Technical Papers, 1900.

45. Matuana, L. M.; Heiden, P. A., 2004: "Wood Composites". In: Encyclopedia of Polymer Science and Technology, J. I. Kroschwitz (ed.), John Wiley \& Sons, Inc., New York.

46. Mishra, S.; Patil, Y. P., 2003: Compatibilizing effect of different anhydrides on cane bagasse pith and melamineformaldehyde-resin composites. J. Appl. Polym. Sci., 88 (7): 1768-1774. http://dx.doi.org/10.1002/app.12207.

47. Najafi, A.; Khademi-Eslam, H., 2011: Lignocellulosic filler/reycyled HDPE composites: effect of filler type on 
physical and flexural properties. BioResources, 6 (3): 2411-2424.

48. Oksman, N. K.; Sain, M., 2008: Wood-polymer composites. Cambridge Wood head Publishing, Ltd, p. 384.

49. Oporto, G. S.; Gardner, D. J.; Bernhardt, G.; Neivandt, D. J., 2007: Characterizing the mechanism of improved adhesion of modified wood plastic composite (WPC) surfaces. J Adhes. Sci. Technol., 21: 1097-1116. http://dx.doi.org/10.1163/156856107782105954.

50. Oporto, G. S.; Gardner, D. J.; Bernhardt, G.; Neivandt, D. J., 2009: Forced air plasma treatment (FAPT) of hybrid wood plastic composite (WPC)-fiber reinforced plastic (FRP) surfaces. Compos Interfaces, 16: 847-867. http://dx.doi.org/10.1163/092764409X12477463089116.

51. Ozen, E.; Kiziltas, A.; Erbas Kiziltas, E.; Gardner. D. J., 2013: Natural fiber blend-nylon 6 composites. Polym. Compos, 34 (4): 544-553. http://dx.doi.org/10.1002/pc.22463.

52. Pandiyaraj, K. N.; Selvarajan, V.; Deshmukh, R. R.; Gao, C. Y., 2009: Modification of surface properties of polypropylene (PP) film using DC glow discharge air plasma. Appl Surf Sci, 255: 3965-3971. http://dx.doi.org/10.1016/j.apsusc.2008.10.090.

53. Park, C. B.; Baldwin, D. F.; Suh, N. P., 1994: Cell. Microcell. Mater., 53: 109.

54. Park, C. B.; Suh, N. P., 1996: Polymer Engineering Science, 36: 34.

55. Park, C. B.; Behravesh, A. H.; Venter, R. D., 1998: Cell. Polym., 17: 309.

56. Punnathannam, S.; Corti, D. S., 2002: Ind. Eng. Chem. Res., 41: 1113-1121.

57. Raj, R. G.; Kokta, B. V.; Nizio, J. D., 1992: Studies on mechanical properties of polyethylene-organic fiber composites. I. Nut shell flour. Journal Applied Polymer Science, 45: 91-101. http://dx.doi.org/10.1002/app.1992.070450111.

58. Riedel, U.; Nickel, J., 2003. Seventh International Conference on Wood fiber-Plastic Composites, May 19-20, Madison, Wisconsin, USA.

59. Rizvi, G.; Matuana, L. M.; Park, C. B., 2000: Foaming of PS/wood fiber composites using moisture as a blowing agent. Polymer Engineering \& Science, 40 (10): 21242132. http://dx.doi.org/10.1002/pen.11345.

60. Schut, J. H., 2001: Foaming expands possibilities for wood-fiber composites. Plastics technology, New York, 47.7: 58-65.

61. Seo, J.; Ohm, W.; Cho, S.; Cha, S. W., 2011: The effect of gas desorption on foaming ratio of microcellular foamed plastics. Polymer-Plastics Technology and Engineering, 50 (1): 8-14. http://dx.doi.org/10.1080/03602559.2010.5 12342.

62. Sperber, V. E., 2002: Fourth International Wood and Natural Fiber Composites Symposium, April 10-11, Kassel, Germany.

63. Takase, S.; Shiraishi, N., 1989: Studies on composites from wood and polypropylenes, II. J. of Applied Polymer Sci, 37: 645-659. http://dx.doi.org/10.1002/app.1989.070370305.

64. Tamrakar, S.; Lopes-Anido, R. A.; Kiziltas, A.; Gardner, D. J., 2011: Time and temperature dependent response of a wood-polypropylene composite. Composites: Part A, 42: 834-842.

http://dx.doi.org/10.1016/j.compositesa.2011.03.011.

65. Tavasoli, F. A.; Talaeipour, M.; Hemmasi, A. H.; Khademieslam, H.; Ghasemi, I., 2011: Investigation on the mechanical and morphological properties of foamed nanocomposites based on wood flour $=$ PVC $=$ Multi-walled carbon nanotubes. BioResource, 6 (1): 841-852.
66. Thoppul, S.; Finegan, J.; Gibson, R., 2009: Mechanics of mechanically fastened joints in polymer-matrix composite structures - a review. Composites Science and Technology, 69 (3-4): 301-329.

http://dx.doi.org/10.1016/j.compscitech.2008.09.037.

67. Verhey, A. S.; Laks, E. P., 2002: Wood particle size affects the decay resistance of woodfiber/thermoplastic composites. Forest Products Journal, 52 (11/12): 78-81.

68. Vinson, J., 1989: Mechanical fastening of polymer composites. Polymer Eng. and Science, 29 (19): 1332-1339. http://dx.doi.org/10.1002/pen.760291905.

69. Wang, H.; Chen, S. J.; Zhang, J., 2009: Surface treatment of LLDPE and LDPE blends by nitric acid, sulfuric acid, and chromic acid etching. Colloid Polym. Sci, 287: 541548. http://dx.doi.org/10.1007/s00396-009-2000-9.

70. Wang, Y.; F. C.; Yeh, S. M.; Lai, H.; Chan, C.; Shan, H. F., 2003: Effectiveness of functionalized polyolefins as compatibilizers for polyethylene-wood flour composites. Polym. Eng. Sci, 43 (4): 933-955. http://dx.doi.org/10.1002/pen.10077.

71. Wechsler, A.; Hiziroglu, S.; Ballerini, A. A., 2008: Some of the Properties of Wood Plastic Composites. Proceedings of the 51st International Convention of Society of Wood Science and Technology November 10-12, Concepción, CHILE.

72. Wolkenhauer, A.; Avramidis, G.; Hauswald, E.; Militz, H.; Viol, W., 2008: Plasma treatment of wood-plastic composites to enhance their adhesion properties. J AdhesSciTechnol, 22: 2025-2037. http://dx.doi.org/10.1163/156856108x332543.

73. Wolkenhauer, A.; Avramidis, G.; Hauswald, E.; Militz, H.; Viol, W., 2009: Sanding vs. plasma treatment of aged wood: a comparison with respect to surface energy. Int J AdhesAdhes, 29: 18-22. http://dx.doi.org/10.1016/j.ijadhadh.2007.11.001.

74. Wood Handbook, 2010: Forest Products Laboratory, United States Department of Agriculture Forest Service, Madison, Wisconsin.

75. Woodhams, R. T.; Thomas, G.; Rodgers, D. D., 1984: Wood fibers as reinforcing fillers for polyolefins. Polymer Engineering and Sci, 24 (15): 1116-1171. http://dx.doi.org/10.1002/pen.760241504.

76. Yam, K.; Gogoi, B.; Lai, C.; Selke, S., 1990: Composites from compounding wood fibers with recycled high density polyethylene. Polymer Engineering and Science, 30 (11): 693-699. http://dx.doi.org/10.1002/pen.760301109.

77. *** 2016a: https://www.google.com.tr/search?q=Wood+ fiber+filled+thermoplastics + composites $+($ WPC $)+$ and + it $\mathrm{s}+$ applications \&biw $=1138 \&$ bih $=543 \&$ source $=1 \mathrm{nms} \&$ tb $\mathrm{m}=\mathrm{isch} \& \mathrm{sa}=\mathrm{X} \& \mathrm{ved}=0$ ahUKEwiy68frw83LAhVIRyYK HZwNBE8Q_AUIBigB, Accessed: 03.02.2016.

78. ***, 2016b: http://catalog.flatworldknowledge.com/ bookhub/reader/2547? e=gob-ch15_s08, Accessed: 03.02.2016.

79. *** 1990: ARCO Chemical Company, Dylark Engineering Resins. Brochure \#ACC-P102-907. ARCO Chemical Co. 3801 West Chester Pike, Newtown Square, Pa.

\section{Corresponding address:}

\section{Lect. Mustafa ZOR, M.Sc.}

Furniture and Decoration Programme

Caycuma Vocational School

University of Bulent Ecevit

67900, Caycuma/Zonguldak, TURKEY

e-mail: mustafa.zor@beun.edu.tr 